\title{
It's Déjà Vu All Over Again: The Intelligent Design Movement's Recycling of Creationist Strategies
}

\author{
Barbara Forrest
}

Published online: 14 April 2010

(C) Springer Science+Business Media, LLC 2010

\begin{abstract}
The intelligent design (ID) creationist movement is now a quarter of a century old. ID proponents at the Discovery Institute, headquartered in Seattle, WA, USA, insist that ID is not creationism. However, it is the direct descendant of the creation science movement that began in the 1960s and continued until the definitive ruling against creationism by the US Supreme Court in Edwards v. Aguillard 1987, which struck down laws that required balancing the teaching of evolution with creationism in public schools. Already anticipating in the early 1980s that Arkansas and Louisiana "balanced treatment" laws would be declared unconstitutional, a group of creationists led by Charles Thaxton began laying the groundwork for what is now the ID movement. After Edwards, Thaxton and his associates promoted ID aggressively until it, too, was declared unconstitutional by a federal judge in Kitzmiller et al. v. Dover Area School District 2005. Subsequently, in 2008, the Discovery Institute began its multistate promotion of model "academic freedom" legislation that bears striking parallels to the 1980s balanced treatment laws. Because of Kitzmiller, ID proponents have written their model legislation in code language in an effort to avoid another court challenge. Yet despite attempting to evade the legal constraints imposed by Edwards, they are merely recycling earlier creationist tactics that date back to the late 1970s and early 1980s. The tactics that ID creationists now usepromoting legislation, publishing "educational" materials, establishing a "research" institute, and sanitizing their
\end{abstract}

\section{B. Forrest $(\bowtie)$}

Southeastern Louisiana University,

SLU 10484, University Station,

Hammond, LA 70402, USA

e-mail: bforrest@selu.edu terminology - are the recycled tactics of their creation science predecessors.

Keywords Creationism · Intelligent design · Discovery Institute $\cdot$ Balanced treatment laws $\cdot$ Academic freedom legislation · Louisiana Science Education Act · Bobby Jindal - Louisiana Family Forum .

National Center for Science Education

\section{Introduction}

The intelligent design (ID) creationist movement has now existed long enough for a child to be born, grow up, finish college, earn a master's degree, and begin a career. ID is a quarter of a century old, having formally begun in 1984 with publication of The Mystery of Life's Origin (Thaxton et al. 1984; Dembski 1998). The lead author, Charles Thaxton, conferred upon the movement its "intelligent design" nomenclature in 1988 (Witham 2002). Its now well-known "Wedge Strategy" began in 1991 with the publication of Darwin on Trial by Phillip E. Johnson, the movement's leader and advisor (Johnson 1991, 1999; Forrest and Gross 2007b). In 1996, ID proponents found an organizational home as the Center for the Renewal of Science and Culture (CRSC) within the Discovery Institute (DI), a conservative Seattle think tank (Discovery Institute 1996). This creationist wing of DI, now called the Center for Science and Culture (CSC), is the command center from which the ID movement is orchestrating its attempt to get ID into public school science classrooms. Everyone who is concerned about the integrity of science education, but especially school administrators and teachers who teach evolution and related sciences, must learn to recognize the tactics by which the DI is continuing the decades-old creationist attack on science education. 
Creationism has become a multigenerational problem in the United States, having first arisen as an early twentieth century reaction against evolution that culminated with the 1925 Scopes trial. In 1961, as a backlash against renewed national emphasis on teaching evolution, the young-earth "creation science" movement (also called "scientific creationism") began with publication of The Genesis Flood (Whitcomb and Morris 1961; Scott 2009). The ID movement, comprised of mostly old-earth creationists such as Thaxton, succeeded creation science as the most culturally aggressive and politically influential form of creationism after the latter's legal demise in 1987, when the US Supreme Court struck down Louisiana's 1981 Act 685, the "Balanced Treatment for Creation-Science and Evolution-Science Act" (Edwards v. Aguillard 1987). However, as Nick Matzke shows in an important article examining the early foundations of ID, when the Louisiana law and a similar one in Arkansas, Act 590, were passed in 1981, Thaxton and his creationist associates were already planning creationism's next phase of development (Matzke 2009). But before they could get very far, they had to figure out how to deal with federal district Judge William Overton's 1982 ruling that Act 590 was unconstitutional, a ruling based partly on the blatantly religious content of creationist literature and the corresponding lack of acceptable teaching materials for public schools, of which Overton took specific note: "The defendants did not produce any text... which they claimed was usable in the public school classroom" (McLean v. Arkansas 1982).

Anticipating a victory in the Louisiana case, Thaxton and Jon Buell, director of the Foundation for Thought and Ethics, a small Christian think tank in Texas, believed that the McLean defeat could have been averted by the availability of appropriate teaching materials. They therefore decided to produce a high school textbook that, according to an announcement in a creationist newspaper, would "present both evolution and creation while limiting discussion to scientific data" (quoted in Matzke 2009). As is now widely known, that book was eventually published, first in 1989 and again in 1993, as Of Pandas and People (Davis and Kenyon 1993). However, Pandas marked a significant strategy shift that was necessitated by the creationists' second defeat in the 1987 Edwards ruling. The creationist content in Pandas now had to be disguised in a way that its promoters hoped would enable them to skirt the Supreme Court's decision while still making the content recognizable as creationism. The explicit creationist language in which numerous prepublication drafts of Pandas had been written was therefore suddenly expunged and replaced with ID terminology after the Edwards decision was handed down on June 19, 1987 (Forrest 2005c). Creation science thereby morphed into "intelligent design," and ID proponents subsequently advanced to the front lines of the creationist effort (Forrest and Gross 2007b; Matzke 2009). Indeed, Pandas co-author Dean H. Kenyon, himself a young-earth creationist, has explicitly recognized the relationship between ID and its predecessor: "Scientific creationism, which in its modern phase began in the early 1960s, is actually one of the intellectual antecedents of the Intelligent Design movement" (Wiker 2000). Although young-earth creationism had (and still has) a larger demographic presence in the United States than ID, the old-earth ID leadership has moved creationism to new levels of political influence.

From 1988 until 2005, Thaxton and his allies, acquiring an operational base at the DI in 1996, spoke in the lingo of "intelligent design theory" in an attempt to camouflage their creationist identity. But this camouflage was stitched together to be worn only when speaking to the American public, policymakers, and the mainstream media; when addressing their religious followers, ID proponents invariably revert to their overtly creationist vocabulary (Hartwig 1995). Moreover, writing in 1999 for an orthodox Christian magazine, DI fellow William Dembski defined ID as "the Logos theology of John's Gospel restated in the idiom of information theory" (Dembski 1999b: 84). (ID creationists, who are mostly old-earth creationists, base ID on John's Gospel rather than Genesis in an effort to avoid divisive arguments with their young-earth allies over Earth's age [Forrest 2007b]). ${ }^{1}$ So, ID is not only a religious but also an overtly Christian belief based on the New Testament. In fact, Dembski, after recently having his creationist integrity impugned by being called a "theistic evolutionist" on a religious website (Helms 2009), admitted forthrightly that he is an old-earth creationist. He also explicitly linked his creationism to his defense of Christianity: "I'm an old-earth creationist.... Basically, what I'm trying to do is preserve Christian orthodoxy within an old-earth perspective" (Dembski 2010). Such candor to a religious audience is at odds with both Dembki's and DI's disingenuous denials to mainstream audiences that ID is creationism.

It was only a matter of time before ID creationists' verbal subterfuge caught up with them. As happened to their young-earth creationist predecessors, DI's relentless promotion of ID eventually generated a federal legal case,

\footnotetext{
${ }^{1}$ ID leaders follow Phillip Johnson's "big tent" strategy, under which they have tried to ally with young-earth creationists to amplify ID's influence. Discovery Institute fellow and young-earth creationist Paul Nelson is the ID movement's liaison to the YEC community (Nelson 2002). Although Pandas predates the big tent strategy, it is an early example of this alliance: Thaxton, the academic editor, is an old-earth creationist; co-authors Davis and Kenyon are young-earth creationists. The book gives a nod to both views (Davis and Kenyon 1993: 92). Although the alliance is uneasy, YEC's blatantly biblical content leaves its supporters little choice except to hope that the ID movement succeeds, thereby forging an opening that will allow them to follow ID into public schools.
} 
Kitzmiller et al. v. Dover Area School District (2005). Eleven parents filed suit in December 2004 after the Dover, Pennsylvania, School Board adopted a policy requiring science teachers to present ID as a scientific alternative to the theory of evolution and then placed Pandas in the school library as a scientific reference book. ${ }^{2}$ However, like creation science in McLean and Edwards, ID could not survive the legal scrutiny to which the plaintiffs' expert witnesses and attorneys subjected it in Kitzmiller. On December 20, 2005, Judge John E. Jones III, Middle District of Pennsylvania, ruled that teaching ID is unconstitutional (Kitzmiller et al. v. Dover Area School District 2005). The courtroom dissection of ID by the plaintiffs' expert witnesses and attorneys - during which the terminology swap in Pandas was exposed-was stunning. This dissection was made possible by the clear, direct, and irrefutable line of descent from creation science to ID. This ancestral lineage is traceable not only because of the continuity in content between creation science and ID (Forrest 2005b) but also because of the ID movement's constant recycling of the strategies of their creationist predecessors from the 1980s and even earlier.

Even though such strategies have been repeatedly discredited, teachers and administrators can more effectively fend off challenges to evolution from creationist parents and students, school board members, and legislators by learning to recognize them (Moore 2004). Among these strategies are the promotion of creationist legislation, the publication of "educational" materials, the establishment of putative "research" institutes, and the sanitizing of their terminology in an effort to conceal their true identity (Forrest and Gross 2007b). ${ }^{3}$ Even in the wake of Kitzmiller, when ID proponents have been forced to reinvent themselves yet again, they have confirmed their identity as creationists by continuing this recycling of "creation science" tactics. To quote Yogi Berra, when it comes to the strategies through which ID creationism has managed to advance into the twenty-first century, "It's déjà vu all over again."

\footnotetext{
${ }^{2}$ DI did not initiate this policy and attempted - unsuccessfully- to persuade the Dover school board to withdraw it. However, once the lawsuit was filed, DI had no choice but to help defend the product it had so successfully marketed. Two DI fellows, Michael Behe and Scott Minnich, testified for the defense as expert witnesses. Three othersStephen Meyer, William Dembski, and John Angus Campbell-had agreed to be defense experts but withdrew when the Thomas More Law Center, legal counsel for the school board, refused to let them bring their own attorneys into the case. Having already been deposed before Meyer, Dembski, and Campbell withdrew, Behe and Minnich remained with the case (Forrest and Gross 2007b).

${ }^{3}$ These strategies are discussed because they are currently the most prominently used. This list is not exhaustive.
}

\section{Creationist Legislation ${ }^{4}$}

ID creationists, as integral members of the Religious Right, believe that American public education and culture are doomed by their constitutionally established secularity (Discovery Institute 1998; Forrest and Gross 2005). Evolutionary theory, like all scientific disciplines, is a product of the naturalistic methodology of modern science. As such, it does not incorporate the theistic component that creationists consider vital not only to science but even to nonscience disciplines such as history. Creationists either ignore or fail to understand the distinction between science's naturalistic methodology, under which scientists must seek only natural explanations of natural phenomena (methodological naturalism), and a comprehensive, nontheistic view of the universe that denies the existence of the supernatural (metaphysical naturalism). Consequently, they regard teaching evolution to schoolchildren as tantamount to teaching atheism. Since they believe that such instruction will undermine children's faith and consequently their morality, they are committed to getting ID into science classes in order to undermine the teaching of evolution. (The initial name of DI's creationist wing, the CRSC, mirrors this commitment.) Recognizing the potential power to be cultivated by influencing the next generation of adults -American schoolchildren - both creation science proponents and ID creationists have tried to establish a beachhead in public schools through legislation. To accomplish this in the decentralized American public education system, they need the sanction of individual state legislatures. Within the span of roughly one generation, they have scored three legislative successes.

Their first two victories were the passage on March 19 and July 20, 1981, respectively, of Arkansas Act 590 and Louisiana Act 685, both entitled the "Balanced Treatment for Creation-Science and Evolution-Science Act" (Arkansas Act 590 1981; Louisiana Act 685 1981). According to a November 1981 report by the Louisiana Department of Education after passage of Act 685, "similar bills [were] currently being examined by almost one third of the state legislatures across the country" (Rachal 1981). According to historian of science Ronald Numbers, the number of states that considered such legislation was actually 22 (Numbers 1992: 320), equaling 44 percent of state legislatures.

Arkansas Act 590 was overturned at the federal district court level in 1982 (McLean v. Arkansas 1982). Louisiana Act 685 was struck down by the US Supreme Court in 1987 (Edwards v. Aguillard 1987). Although proscience advocates hoped that Edwards would end the problem of creationism in

\footnotetext{
${ }^{4}$ This paper deals only with creationist legislation that began with the "balanced treatment" laws of the early 1980s. Earlier legislation such as Tennessee's 1925 Butler Act is not discussed.
} 
the United States - indeed, it was the death-knell for blatant, young-earth creationism, at least in terms of legislative sanction-ID creationists are determined to defy the Edwards ruling. The DI first assumed a national profile in 1999, when it aided and abetted the Kansas State Board of Education's effort (initiated by local young-earth creationists) to remove evolution from the state science standards (Forrest and Gross 2007b). Even after Kitzmiller, DI persists in its attack on public school science education. Although the force of Judge John E. Jones' reasoning in that case has deterred several subsequent creationist efforts (National Center for Science Education 2006; Forrest and Gross 2007b), his decision is technically binding only in the Middle District of Pennsylvania. Taking full advantage of Kitzmiller's limited jurisdictional reach, ID has now become creationism's legislative stalking horse across the country.

Although Phillip Johnson has denied both that public schools are the proper "venue" for ID (Barbero 1993) and that the movement seeks legislative sanction for teaching it (Athitakis 2001), legislative protection for teaching ID in public schools has been the movement's goal since its inception. The CRSC's "Wedge Strategy," outlined in a written action plan that stretches over 20 years (19982018), specifies that the group seeks "Legal reform movements [that] base legislative proposals on design theory" and that it is prepared to "pursue possible legal assistance in response to resistance to the integration of design theory into public school science curricula" (Discovery Institute 1998). Johnson reconfirmed this goal in 2003: "Our strategy has been to change the subject a bit so that we can get the issue of intelligent design, which really means the reality of God, before the academic world and into the schools" (Johnson 2003). But DI's post-Kitzmiller notoriety requires that they now disguise pro-ID legislation with code language in an attempt to evade almost a dozen federal court decisions in which creationists have consistently lost (Matsumura and Mead 2007).

Just as creationists tried after Edwards to disguise creation science with the "new" concept of ID, so now, after Kitzmiller, ID is disguised as, among other things, "academic freedom" (see below for other code terms). In early 2006, just after the Kitzmiller ruling, DI announced, "We have entered a new front in the debate over intelligent design - the need to protect academic freedom" (Discovery Institute 2006). On February 7, 2008, DI posted its deceptively named "Model Academic Freedom Statute on Evolution [version 9/7/2007]" on a special website (Discovery Institute 2007; National Center for Science Education 2009b). ${ }^{5}$ That year, variants of this model bill were

\footnotetext{
${ }_{5}^{5}$ Since the draft of the Discovery Institute's model bill is dated 2007, I refer to it as the 2007 model bill, although DI's multistate campaign to promote it began in 2008 .
}

introduced in six states (National Center for Science Education 2009a). On June 25, 2008, Louisiana became the first and, so far, only state to adopt one of them when Gov. Bobby Jindal signed Senate Bill 733 into law as Act 473, the Louisiana Science Education Act (LSEA) (Louisiana Act 473 2008). Senate Bill 733 had initially been introduced as SB 561, the "Louisiana Academic Freedom Act" (Louisiana SB 561 2008).

The continuity between Louisiana's 1981 Act 685, DI's 2007 model bill, and the 2008 LSEA is striking in a number of respects (which are too numerous to include in their entirety). Moreover, all three bills are directly traceable to earlier efforts at least as far back as creationist lawyer Wendell Bird's 1979 "Resolution for Balanced Presentation of Evolution and Scientific Creationism," which invoked the obligation of public schools "to provide academic freedom for students' differing values and beliefs" by offering "the theory of special creation" (Bird 1979). (Bird was the lead attorney for the state of Louisiana in the Edwards case [Keith 1982].) The language of Act 685 specified that it was "enacted for the purposes of protecting academic freedom" and that "no teacher in public elementary or secondary school... who chooses to be a creationscientist or to teach scientific data which points to creationism shall... be discriminated against in any way" (Louisiana Act 685 1981). A comment by Gov. David Treen, who signed the legislation, indicated that he had bought into the charade: "Academic freedom can scarcely be harmed by inclusion; it can be harmed by exclusion" (New York Times 1981).

Much like the balanced treatment bills of the 1980s, DI's 2007 model bill stipulates that "This law shall be known as the "Academic Freedom Act"' and that "No K-12 public school teacher or teacher... shall be terminated, disciplined, denied tenure, or otherwise discriminated against for presenting scientific information pertaining to the full range of scientific views regarding biological or chemical evolution" (Discovery Institute 2007). The "full range of views" in the DI model bill is code language for teaching ID (Forrest and Gross 2007b: 337). Although Bobby Jindal signed the LSEA without public comment, he had already signaled his support for teaching creationism during both his 2003 and 2007 gubernatorial campaigns, using typical creationist doubletalk. His 2003 comments indicate that he had picked up at least one ID code term: "If a teacher wanted to say (creationism) is what some people believe and presented a range of views, there's nothing wrong with that" (Thevenot 2003) (emphasis added). His 2007 comments came in response to a journalist's question specifically about ID:

There's no theory in science that could explain how, contrary to the laws of entropy, you could create order 
out of chaos. There's no scientific theory that explains how you can create organic life out of inorganic matter. I think we owe it to our children to teach them the best possible modern scientific facts and theories. Teach them what different theories are out there for the things that aren't answerable by science, that aren't answered by science. Let them decide for themselves.... Personally, it certainly makes sense to me that when you look at creation, you would believe in a creator. (quoted in Forrest 2007a)

Jindal's campaign signals fell on receptive ears in both Seattle and Baton Rouge. In 2008, DI partnered with the Louisiana Family Forum (LFF), a Religious Right group, to write and promote SB 561 (Discovery Institute 2008; Louisiana Family Forum 2009). The bill was introduced by LFF ally, Louisiana Senator Ben Nevers, on March 21, barely two months after Jindal's January 14 inauguration. DI's influence is evident in both versions, SB 561 and SB 733, and the creationist ancestry is clear. Like Act 685, DI's model bill purports to protect "academic freedom" and contains a provision to shield creationist teachers from being held accountable for their curricular transgressions. Reflecting both the language (slightly reworked) and intent of DI's model bill, SB 561 stipulated that "this act shall be known as the "Louisiana Academic Freedom Act"' and attempted to protect creationist teachers by mandating that neither the Louisiana Department of Education nor any school official at any level "shall prohibit any teacher in a public school system... from helping students understand, analyze, critique, and review in an objective manner the scientific strengths and scientific weaknesses" of "biological evolution, the chemical origins of life, global warming, and human cloning" (Louisiana SB 561 2008). ${ }^{6}$ Although the "strengths and weaknesses" language is part of DI's post-Kitzmiller strategy of avoiding overt references to ID (Forrest 2007b; Beil 2008), this precise phrase is itself a direct inheritance from creation science. Richard Bliss of the young-earth Institute for Creation Research (ICR) had used it almost 30 years earlier when the balanced treatment bills were being litigated: "Scientific creationists... think that evolution should be taught, but only when the strengths and weaknesses are discussed in comparison with the scientific merits of creation" (Bliss 1983).

When opposition to SB 561 surfaced, the bill's proponents - probably fearing that they were sticking too closely to the historical script — sanitized the language even further

\footnotetext{
${ }^{6}$ Global warming and human cloning are included not only because the Religious Right opposes both but also to deflect the charge that creationists always single out evolution for attack. However, virtually all public statements by proponents of the LSEA have dealt only with evolution, providing strong evidence that evolution is the law's true target.
}

and reintroduced the bill as SB 733, the "Louisiana Science Education Act," this time emphasizing "critical thinking" as the operative code phrase (Louisiana Act 473 2008). DI fellow David DeWolf acknowledged helping to craft the language (Discovery Institute 2008). ${ }^{7}$ But this phrase, too, is a traditional creationist ploy, having also been used by Bliss: "The nature and methodology of science and science education should require an open and inquiry-oriented approach to the creation/evolution question.... [T] he question of origins enhances critical thinking through a decision-making framework" (Bliss 1983).

The DI's model academic freedom bill and its variants such as the Louisiana law are particularly pernicious. Like the legislation of the early 1980 s, they attempt to shift the balance of power concerning curricular content to individual teachers, school boards, parents who demand that creationism be taught, and students who are coached to challenge their teachers. The latter scenario actually happened in Louisiana. Dominique Ditoro Magee, along with her mother Lenni Ditoro, testified in favor of the LSEA before the Louisiana House and Senate Education Committees in 2008. Seven years earlier, in a 2001 interview as a high school student, she had explained how-prompted by her mothershe persuaded her biology teacher to allow her to challenge evolution in class.

[Question] When did you start to study evolution and creation science?

[Dominique Ditoro] I was assigned to do a persuasive speech in my freshman speech class. I decided to disprove the theory of evolution. I really got into it and learned a lot for the 10-minute presentation. I did well and blew away the student on the other side of the debate....

[Question] What made you pick that topic for your speech?

[Ditoro] My mom has definitely led me to speak out and stand up for what is right....

[Question] How did other people in your class react?

[Ditoro] A lot of people were uncomfortable. Even my teacher believed in evolution....

[Question] So how did that affect your biology class this year?

[Ditoro] We were just starting a section on evolution and human origins. I was able to talk about the evidence against the assumptions that the book was

\footnotetext{
${ }^{7}$ DeWolf had helped revise an earlier academic freedom bill in Alabama in 2004. After the Alabama Senate Education Committee passed SB 336, DeWolf helped sanitize the language prior to the House Education Committee vote (DeWolf et al. 2004). The House version "replaced the 'alternative theories' language with language protecting the presentation of only 'scientific information' on the 'full range of scientific views"” (Matzke 2004).
} 
treating as factual information. That really impressed my teacher... This inspired my teacher to find out more. She started talking to all the other biology teachers in my school.... There is so much evidence against evolution, but the textbooks present this theory so factually. It confuses students. I feel they either need to put creation in the textbooks, too, or take evolution out. (Concerned Women for America 2001)

The Louisiana law, designed to provide legal cover for creationist teachers and sympathetic school boards, now permits (but - importantly - does not require) teachers to use creationist "supplementary materials" in addition to mandatory, state-approved textbooks. It thus enables them to bypass state science standards, textbook selection procedures, and other curriculum safeguards. Even proevolution teachers, especially young, inexperienced ones, are now vulnerable to pressure from parents, students, and school boards to supplement state-approved teaching materials with bogus creationist materials. Dominique Ditoro Magee used creationist "textbook addendums" that her mother had given her. These addendums, written by creationist Charles Voss for all of the state-approved biology textbooks in Louisiana, are readily available on the Internet to teachers, parents, and students (TextAddOns.com 2003; Forrest 2008a). With materials like these so easily available to teachers, principals will now find their hands tied when trying to ensure that every teacher in the school teaches science properly. Proevolution teachers will be faced with undoing damage that creationist colleagues did to their students in previous classes. Moreover, legislation such as Louisiana's creates the distinct possibility that creationist parents whose demands are not met will feel emboldened to file lawsuits against school systems that refuse to teach creationism, thus reversing the traditional scenario in which proscience parents sue school systems for teaching it.

The LSEA remains on the books in Louisiana. Although variants of DI's model legislation were introduced in seven additional states in 2009, none was adopted. DI succeeded in Louisiana not because of any progress its "researchers" had made in establishing the scientific authenticity of ID but because of a unique configuration of political factors centering around the election of Bobby Jindal, along with DI's constant readiness to exploit any opportunity that presents itself (Forrest 2009). But DI will not be satisfied with just one notch on its belt; like their creation science ancestors, ID creationists' most enduring trait is persistence.

\section{"Educational" Materials}

Creationists' machinations for gaining entry into science classrooms would be pointless without teaching materials. Their production of such materials displays a consistent pattern of terminological gymnastics as they try to outrun their federal court losses. In 1982, Thaxton and Buell, heeding Judge Overton's comments in McLean about defendants' failure to produce a public school textbook, prepared to fend off post-McLean legal challenges by producing Pandas as a "supplemental" high school textbook (Davis and Kenyon 1993: 154), only to be forced to replace the book's blatant creationist terminology with ID terminology after Edwards (Forrest 2005c). Creationists had taken a similar tack after the US Supreme Court's 1968 Epperson v. Arkansas ruling that prohibited banning evolution from public schools (Epperson v. Arkansas 1968). ICR founder and young-earth creationist Henry Morris sought to outflank the federal courts by producing two versions of his textbook, Scientific Creationism: (1) a "general edition" with frequent references to the Bible, intended primarily for use in Christian schools, and (2) a "Public School Edition" without the biblical references that would be used "solely as a supplementary textbook" (Morris 1974; Williams 1983). The Kitzmiller decision has necessitated yet another round of terminological evasion, this time by ID creationists.

The DI has for years been preparing ID materials for public schools. In early 2000, DI's website briefly offered an ID curriculum that was "particularly designed to supplement standard science textbooks used in public schools" (quoted in Forrest and Gross 2007b: 162). (It was quickly passworded to block public access.) Although Pandas was intended as a supplementary ID textbook, the Kitzmiller exposé rendered it useless (Forrest 2005c). Two new ID texts have supplanted it: The Design of Life (DoL) (Dembski and Wells 2007) and Explore Evolution (EE) (Meyer et al. 2007). DoL, published by Pandas publisher Buell, is straightforwardly pro-ID. Although Buell touts it as a book that "would vastly increase the probability of bringing academic freedom to science classrooms" (Buell 2008), the promotional website admits that "it was not developed for use in public secondary schools, whose guidelines, developed to circumvent controversy, may not permit this level of open inquiry" (Foundation for Thought and Ethics n.d.).

$E E$, however, is intended for mainstream adoption in public schools. Consequently, just as creationist language in Pandas had to be replaced with ID terminology after Edwards, EE's authors have attempted to avoid overt ID terminology in the wake of Kitzmiller; the term intelligent design does not appear in the book. Yet despite their terminological stealth, the entire book consists of shopworn, long-discredited creationist criticisms of evolution and other undeniable creationist terminology such as the "abrupt appearance" of major animal groups in the Cambrian fossil record (Meyer et al. 2007: 22). This term was used in Pandas (Davis and Kenyon 1993: 22) and 
highlighted in court during the Kitzmiller trial (Forrest 2005d). ID proponent Michael Behe's concept of "irreducible complexity," an identifiable creationist concept that had been invoked by creationist Ariel Roth as "complex integrated structures" in his 1981 McLean trial testimony (Matzke 2009), is explicitly included (Forrest and Gross 2007a; Meyer et al. 2007). Moreover, all of the authors are known creationists; one of them, DI fellow Paul Nelson, is a young-earth creationist (Forrest and Gross 2007b).

Shortly before Bobby Jindal signed the LSEA in June 2008, CSC Associate Director John West told a Louisiana newspaper that DI hoped the law would allow use of supplemental materials such as $E E$ in the state's public schools (Macias 2008). ${ }^{8}$ The $E E$ website, anticipating its use under such legislation and using the same code language found in both SB 561 and SB 733, advertises it as "ideal" for "biology teachers in states that have required or encouraged teachers (1) to help students to critically analyze key aspects of evolutionary theory or (2) to teach both strengths and weaknesses of scientific theories such as neo-Darwinian evolutionary theory" (Discovery Institute n.d.) (emphasis added). But creationists never follow their own strategy with unbroken consistency. They abandon their pretense in friendly settings, as ID proponents did at an August 2007 symposium for science teachers at Biola University, an evangelical Christian school that was founded as the Bible Institute of Los Angeles. (Biola includes ID in the curriculum of its Master of Arts program in Science and Religion [Biola University 2008].) At this symposium, $E E$ was unveiled, and materials and strategies for using it in classrooms were given to attendees (Mead 2008).

Louise Mead, Education Project Director at the National Center for Science Education (NCSE), attended (unrecognized despite using her real name) and reported that the symposium "opened with an evening prayer to 'Our Lord, Jesus Christ"” (Mead 2008). Moreover, "as the symposium proceeded, the climate became overtly hostile toward people who accept evolution" (Mead 2008). Led by DI fellows Jonathan Wells and Michael Keas, one session was marked by the deceitfulness that is integral to ID creationists' strategizing:

Wells... presented evidence for "intelligent design", which is not to be found in the Explore Evolution textbook. He claimed that ID does not rely on biblical authority or religious doctrine and does not tell us the nature of the designer, but went on to inform participants that for him, the designer is the God of the Bible. Of course the Science Teacher Symposium

\footnotetext{
${ }^{8}$ The article mistakenly calls the book Discover Evolution.
}

on Explore Evolution had absolutely "no religious agenda" - a claim continually made by Keas, Wells, and John Bloom, head of the Science and Religion Program at Biola, formerly the Bible Institute of Los Angeles.

The final piece of Wells's advice to participants was what to teach about evolution in the public school science classroom. Only a few of the thirty-odd participants in the room actually taught in a public institution, based on a show of hands. A few teachers, currently teaching at private Christian schools, were concerned about their "rights" should they teach in a public school.... Wells's recommendations, reiterated by Keas in the next sessions of the symposium, were predictable. Teach "critical analysis", the evidence for and against neo-Darwinism, but not "intelligent design”, unless at a private institution supportive of creationism. (Mead 2008)

Mead also noted that the teaching materials provided to attendees were, like the book, riddled with errors. An NCSE staff critique of EE reveals that "Explore Evolution is an unusually bad textbook" (National Center for Science Education 2008). ${ }^{9}$ This assessment is broadly applicable to creationist materials in general. Any teacher who uses them is guilty, at the very least, of gross professional incompetence and, at worst, deliberate dishonesty.

\section{The "Research Institute"}

Creationists need a façade of scientific authenticity in order to appear scientifically credible to journalists and to keep the financial donations flowing. They also must impress their rank-and-file supporters who, with little or no understanding of science, function as surrogates who do the initial groundwork of cultivating school boards and state legislators for oncoming creationist policy initiatives. So, creationists establish "research institutes" to fend off the charge that they produce no scientific data to support their claims. In this respect, DI has again imitated its creation science predecessors. ICR maintains "laboratory facilities" in Dallas, TX, USA (Institute for Creation Research n.d.). The Creation Research Society operates the Van Andel Creation Research Center in Arizona (Creation Research Society 2009), and the DI operates the "Biologic Institute" (BI), with an office in Redmond, WA, USA, and a laboratory in nearby Fremont, WA, USA (Biever 2006; Biologic Institute 2009).

\footnotetext{
${ }^{9}$ The National Center for Science Education in Oakland, CA, USA, is the only clearinghouse in the USA that exists solely to provide assistance and information concerning the problem of creationism. Eugenie Scott is the executive director.
} 
DI's Wedge Strategy document, written in 1998, specified that a "Molecular Biology Research Program" conducted by "Dr. Douglas Axe et al." would commence in "Phase I" (Discovery Institute 1998), but this foundational component of the strategy was the last to get under way. Not until 2005, the year after the Kitzmiller suit was filed, did DI establish the "Biologic Institute"-conveniently dropping the announcement to the New York Times in August 2005 to coincide with its need to appear scientifically authentic as the Kitzmiller trial approached (Chang 2005). (The institute's desire for publicity did not extend to an actual visit by a journalist. When New Scientist reporter Celeste Biever went to Redmond, WA, USA, and attempted to interview Biologic Institute office staff, the door was slammed in her face. See Biever 2006.) Although BI's director, Douglas Axe, had been a CRSC fellow at the DI from 1997 to 1999, his name was removed from the roster in 2000 in what was clearly an effort to give him a measure of plausible deniability while he conducted legitimate research in England (Forrest and Gross 2007b). In 2005, he resurfaced in the United States and assumed an unambiguous, public profile as an ID creationist. Recently featured with DI fellow Jonathan Wells in a pro-ID video, Axe puts his knowledge of molecular biology at the service of the ID agenda by attempting to undermine "Darwinism" (Discovery Institute 2009a). ${ }^{10} \mathrm{He}$ also appears in the reprehensible ID propaganda film entitled Expelled: No Intelligence Allowed (Internet Movie Database 2008; National Center for Science Education 2009c).

Like other creationist research institutes, BI staff has produced no scientific data that support their creationist claims. (Although Axe has published articles in legitimate scientific journals, qualified scientists have judged their value as support for ID to be nil. [Forrest and Gross 2007b].) When mainstream scientists were invited to hear presentations of ID research at a June 2007 DI conference entitled "Emergence vs. Design," the outcome was predictable. Evolutionary biologist Daniel R. Brooks, who attended despite misgivings, found his suspicions about the conference agenda confirmed by the presentations by ID creationists Stephen Meyer, Michael Behe, William Demski, Paul Nelson-and Douglas Axe. In Axe's lecture, "The Language of Proteins - Revisiting a Classic Metaphor with the Benefit of New Technology," Brooks noted Axe's attempt to undermine aspects of protein evolution using the standard creationist argument that, since such processes would require more geological time than was available for them to occur naturally, they must have been designed.

\footnotetext{
$\overline{{ }^{10} \text { Creationists }}$ use the anachronistic term "Darwinism" as a pejorative synonym for evolutionary theory. See Scott and Branch (2009).
}

After the requisite testifying (I used to be an evolutionist until I saw the light), Axe gave a talk focusing primarily on a computer program for proteomics that his company has produced, and presumably is trying to market.

The only connection between ID and this presentation were some statements meant to show that because lots of mutations do not destroy whole genomes, genomes have been designed to withstand mutations. If you look at molecular functions outside of their organic context, they appear so improbable that they must have been designed.... [T] here has not been enough time for the slow, slow Darwinian processes to have produced these results. (Brooks 2008)

Brooks observed that it was difficult to figure out "what [Axe's] presentation had to do with how proteins were produced in the first place, and thus the conference question of design vs. emergence." Moreover, the original data that BI researcher Ann Gauger did produce actually revealed a beneficial evolutionary mutation rather than undermining evolution (Brooks 2008).

Brooks also described the post-conference breach of professional etiquette to which DI subjected mainstream scientist invitees:

A few days after the meeting ended, we all received an email stating that the ID people considered the conference a private meeting, and did not want any of us to discuss it, blog it, or publish anything about it. They said they had no intention of posting anything from the conference on the Discovery Institute's web site (the entire proceedings were recorded). They claimed they would have some announcement at the time of the publication of the edited volume of presentations, in about a year, and wanted all of us to wait until then to say anything. These actions made me aware of the extent to which the ID movement was willing to bear false witness in order to achieve its goals.... (Brooks 2008)

The retroactive secrecy that DI attempted to impose on attendees was likely intended to keep the poor performance of BI researchers from being reported publicly, an effort to which Brooks responded by reporting it publicly. Moreover, three years after the symposium, the promised volume of published presentations still has not appeared.

DI's strategy of using a research institute to enhance ID's credibility has done just the opposite. Axe's and his BI staff's reputations are now sealed: they are creationists working only to advance DI's religio-political agenda. The BI staff roster is peopled with recognizable ID creationists who have so damaged (or sacrificed) their credibility that they now have no respectable alternative venues for conducting their 
"research." So, in yet another respect, ID proponents join their colleagues at the ICR and the Creation Research Society. They continue to deliver conference presentations, but in settings such as the Southwestern Seminary in Fort Worth, TX, USA, where DI fellows recently discussed "a Biblical theology of nature; the role of Christianity in the founding of modern science; the impact of Darwinian Evolution on ethics, society, Biblical studies and theology; and the scientific evidence for intelligent design and its implications for theism" (Discovery Institute 2009b).

\section{Terminological Strategy}

In 1979, ICR attorney Wendell Bird wrote a "Resolution for Balanced Presentation of Evolution and Scientific Creationism" requiring public schools to give "balanced treatment to the theory of scientific creationism and the theory of evolution" for the sake of "academic freedom" (Bird 1979). He supposedly intended it only for individual school boards, not as model state legislation. However, Bird wrote language for one of the "balanced treatment" bills that respiratory therapist Paul Ellwanger was promoting to state legislatures in the late 1970s, two versions of which became Arkansas Act 590 and Louisiana Act 685 (Edwords 1982). These bills were the strategic response to the Supreme Court's 1968 Epperson v. Arkansas decision striking down state laws that banned teaching evolution in public schools.

With these bills-invoking "academic freedom" as the rationale for teaching "creation science"-began the creationist tactic of trying to skirt the US Constitution by sanitizing the language of both legislation and lesser policy proposals after each federal court defeat. This strategy continues today. Its developmental trajectory is clearly traceable, revealing a strong line of tactical-and therefore substantive - continuity between ID and creation science. However, the federal courts' repeated rejection of teaching creationism in any form in public school science classes has forced creationists against the wall, tactically speaking. Ten federal court rulings (Matsumura and Mead 2007), rejecting every angle from which creationists have tried to advance their agenda, have depleted their tactical arsenal. So, ID proponents, rising from the nadir of American creationism after Edwards, have been forced after Kitzmiller to make more strenuous use of code language, even though creationists have used this tactic for decades. Judge Jones, noting that "religious opponents of evolution began cloaking religious beliefs in scientific sounding language" after the 1968 Epperson decision, explicitly recognized the use of this tactic as part of the "historical context" of creationism (Kitzmiller et al. v. Dover Area School District 2005: 21).
One day after the ACLU filed suit against Arkansas Act 590 on May 28, 1981, the Louisiana legislature tried to forestall a legal challenge to its own bill by deleting references to a young earth and worldwide (Noah's) flood (Matzke 2009). However, the Arkansas bill was struck down by Judge Overton in 1982, and the explicit language of "creation science" left Act 685 vulnerable, resulting in the 1987 Edwards ruling that declared it unconstitutional. Thaxton and his associates clearly believed that calling creationism "intelligent design" would enable it to withstand legal challenges, as Matzke explains.

The political/legal strategy of "creation science" collapsed suddenly in 1981-1982. The next legal strategy was to strip down creation science to make it appear even less sectarian than before. When the stripped-down creationism strategy failed in Edwards, a few creationists decided to try again with a new label, and that is why "intelligent design" is the term on our lips today. (Matzke 2009)

However, given ID proponents' periodic candor about their true identity and the fact that "intelligent design" is a religious concept that was used by Thomas Aquinas in the thirteenth century and by nineteenth century theologian William Paley (Behe 1996; Dembski 1999a), ID's critics have quite easily exposed it as creationism (Forrest and Gross 2007b). Consequently, DI recognized its "new" alias as a legal liability and began to sanitize its terminology even before Kitzmiller (Forrest and Gross 2004). By the time DI began peddling its model academic freedom bill in 2007, a complete set of recycled code terms had publicly supplanted "intelligent design" for policy-making purposes. DI now claims - to the media, state legislatures, and state boards of education - that its sole interest is promoting "critical thinking" or the "critical analysis" of evolution; teaching the "strengths and weaknesses" of, the "evidence for and against," or "the controversy" about evolution; presenting the "full range of views" about evolution; and, of course, promoting "academic freedom" (Forrest 2007b). The goal now, as in 1981, is to slither past the federal courts by means of verbal technicalities. With respect to the 2008 LSEA, the goal was to avoid mentioning either "creationism" or "intelligent design" in the language of the bill. But the tactic of sanitizing the language of legislation was recognized even in 1981, as a Shreveport Times editorial perceptively noted after the passage of Louisiana Act 685:

What is now to be seen is whether or not the semantics will play in court....

What the ACLU will have to prove... is that the term "scientific creationism" is a semantic sham, and that... it... is, in fact, religion.... That may not be as easy as you'd think. You may believe that it's just a 
masquerade for teaching religion in the public schools... but proving it, given the terminology set forth by creationism and its advocates, is another matter entirely.

It is that terminology, most likely, which led Governor Treen to remark... that when the ACLU lawyers read the Louisiana bill, they may want to drop their court challenge here. The language is carefully chosen and constructed to avoid mention of religion, or the imposition of religious beliefs in the classroom. Again, tricky. And politically, very shrewd. The people who put this movement together are not amateurs; anyone who thinks they are is woefully underestimating them. (quoted in Keith 1982: 29-30)

The Supreme Court, however, saw through the terminological ruse. Quoting language used by the Edwards defense that is strikingly similar to the sanitized ID terminology of today, the Court refused to accept the state of Louisiana's academic freedom argument:

True, the [Balanced Treatment] Act's stated purpose is to protect academic freedom.... The Court of Appeals, however, correctly concluded that the Act was not designed to further that goal. We find no merit in the State's argument that the "legislature may not [have] use[d] the terms 'academic freedom' in the correct legal sense. They might have [had] in mind, instead, a basic concept of fairness; teaching all of the evidence." Even if "academic freedom" is read to mean "teaching all of the evidence" with respect to the origin of human beings, the Act does not further this purpose. (Edwards v. Aguillard 1987) (emphasis added)

Just as Louisiana Senator Bill Keith and his creationist associates who authored Act 685 did not succeed in writing a semantically clean bill in 1981, so DI and the LFF failed in 2008 to sufficiently camouflage the connection between the LSEA and its creation science predecessors, as already shown above. Throughout the entire span of 30 yearsfrom Bird's 1979 resolution, to the 1981 balanced treatment laws, to DI's 2007 model academic freedom bill, to the 2008 LSEA - the basic ideological framework and the charade of academic freedom remain. Only the terminology used to refer to the creationist content has been changed in the aftermath of each judicial ruling.

Moreover, unlike the Shreveport Times' observation regarding Act 685, the LSEA does not avoid religion but rather includes from DI's model bill a transparent attempt at pre-emptive legal self-defense in the form of a religion disclaimer. In this respect, the LSEA more closely resembles Arkansas Act 590, which included several such disclaimers, two of which specified that "this Legislature enacts this Act... with the purpose of... preventing discrimination against students on the basis of their personal beliefs concerning creation and evolution," and that "this Legislature does not have the purpose of causing instruction in religious concepts or making an establishment of religion" (Arkansas Act 590 1981). The LSEA disclaimer specifies that the law "shall not be construed to promote any religious doctrine, promote discrimination for or against a particular set of religious beliefs, or promote discrimination for or against religion or nonreligion" (Louisiana Act 473 2008). In a statute supposedly related only to science education, such a disclaimer would be included only because the law is precisely about religion (Forrest 2008b). This disclaimer is the thread uniting all versions of DI's model bill introduced in state legislatures in 2008 and 2009. Only in Louisiana does it have the sanction of law.

\section{Conclusion}

Given the history of creationism in the United States, one prediction is entirely safe: although creationists have produced neither new scientific data nor new tactics, they will keep coming back to the schoolhouse, the statehouse, and inevitably, the courthouse. They will continue their constant, aggressive cultivation of publicity, which they now accomplish more effectively than ever via the Internet. They will keep reinventing themselves, or more accurately, reshuffling their tactics, pulling old ones out of cold storage when they think - usually correctly - that enough time has gone by so that their targeted populations will not recognize them. The only effective antidote is constant vigilance and recognition of their strategies and warning signals; even with their limited tactical repertoire, they often catch their victims by surprise. Because of consistent defeats in federal court, creationists' most sought-after prize - state legislation - had eluded them until passage of the LSEA in 2008. Consequently, they had targeted state science standards, as in Kansas in 1999 and Ohio in 2001 (Forrest and Gross 2007b), and the selection of biology textbooks, most famously as in Texas in 2003 (Evans 2003). Legislation such as Louisiana's channels creationism directly into the classroom of any teacher who is incompetent or unprofessional enough to take advantage of such laws.

While the Religious Right was riding the wave of its national political influence during George W. Bush's administration, the DI tried in 2001 to blanket the entire country with its influence by having an ID-friendly sense of the Senate resolution attached to the No Child Left Behind Act, an effort that fortunately failed (Forrest 2007b; Forrest and Gross 2007b: ch. 8). With ID's national influence having been checked (for the time being) by the election of 
Barack Obama, both young-earth and ID creationists have redoubled their efforts at the state level, from which they will continue targeting state science standards and textbook selection processes. The DI's success in Louisiana guarantees that the ID movement will continue its legislation strategy. When state-level initiatives fail, ID operatives will simply drop to the county and local levels, seeking inroads with friendly school boards. When they fail at the level of the school board, they will settle for cooperation from individual teachers. This is why the most effective barrier against creationism is ultimately classroom teachers, who are legally permitted and morally obligated to refuse to cooperate with initiatives such as the LSEA. Creationists will always keep coming back, always aiming for the broadest—or the narrowest-level of influence accessible to them.

Nonetheless, precisely because ID creationists have done such an effective job of conveying to their religious supporters that ID is creationism, and thus a religious belief (Forrest 2005a), and precisely because proscience advocates have done such an effective job of exposing this fact in their scholarship, the media, and federal court, ID proponents now have no alternative other than to recycle the creationist strategies of decades past. As seen above, using code language to enshroud creationism in superficially nonreligious language is a time-honored creationist strategy - or, rather, a time-honored strategic necessity. Although the ID movement is the beneficiary of the tactical lessons learned by earlier creationists, it has not changed the central message that its followers all understand: (1) ID is creationism, and therefore a religious belief; (2) the designer is the Christian God of the New Testament; and (3) ID proponents are on a religious mission to save western culture from the evils emanating from modern science and secularism. Nothing can change that.

\section{References}

Arkansas Act 590. Balanced treatment for creation-science and evolution-science act. 1981. http://www.antievolution.org/projects/ mclean/new site/legal/act 590.htm. Accessed 27 Oct 2009.

Athitakis M. Looking for God at Berkeley. San Francisco Weekly. 2001. http://www.discovery.org/a/664. Accessed 27 Oct 2009.

Barbero Y. Interview with Phillip E. Johnson. 1993. http://rnaworld. bio.ku.edu/ID-intro/cast/johnson/johnson.htm. Accessed 27 Oct 2009.

Behe MJ. Darwin's black box. New York: Simon \& Schuster; 1996.

Beil L. Opponents of evolution adopting a new strategy. New York: The New York Times; 2008. http://www.nytimes.com/2008/06/ 04/us/04evolution.html. Accessed 30 Oct 2009.

Biever C. Intelligent design: the God lab. New Scientist. 2006. http:// www.newscientist.com/article/mg19225824.000-intelligent-designthe-god-lab.html. Accessed 15 Feb 2010.

Biola University. Intelligent design theory and Biola. 2008. http:// www.biola.edu/id/. Accessed 11 Feb 2010.
Biologic Institute (website). 2009. http://www.biologicinstitute.org/. Accessed 15 Nov 2009.

Bird WR. Resolution for balanced presentation of evolution and scientific creationism. Impact. 1979. http://www.icr.org/article/resolution-forbalanced-presentation-evolution-sci/. Accessed 31 Oct 2009.

Bliss R. Evolutionary indoctrination and decision-making in schools. Impact. 1983. http://www.icr.org/article/evolutionaryindoctrination-decision-making-school/. Accessed 30 Oct 2009.

Brooks DR. ID: intelligent design as imitatio Dei (report on the 2007 "Wistar Retrospective Symposium"). np: Panda's Thumb. 2008. http://pandasthumb.org/archives/2008/02/id-intelligent.html. Accessed 7 Nov 2009.

Buell J. Fundraising letter. Richardson: Foundation for Thought and Ethics; 2008.

Chang K. In explaining life's complexity, Darwinists and doubters clash. New York: The New York Times; 2005. http://www.nytimes.com/ 2005/08/22/national/22design.html?_r=1\&pagewanted=all. Accessed 7 Nov 2009.

Concerned Women for America. Closeup: a CWA member who makes a difference. Family Voice; 2001.

Creation Research Society. CRS Van Andel Creation Research Center. 2009. http://www.creationresearch.org/vacrc/vacrc.html. Accessed 7 Nov 2009.

Davis PW, Kenyon DH. Of pandas and people: the central question of biological origins. Dallas: Haughton Publishing Co.; 1993.

Dembski WA. The intelligent design movement. Cosmic Pursuit. Colorado Springs: Access Research Network; 1998. http://www.arn.org/docs/ dembski/wd idmovement.htm. Accessed 23 Oct 2009.

Dembski WA. Intelligent design: the bridge between science and theology. Downers Grove: InterVarsity Press; 1999a.

Dembski WA. Signs of intelligence: a primer on the discernment of intelligent design. Touchstone. 1999b;12(4):76-84.

Dembski WA. Johnny T. Helms' concerns about my book The End of Christianity. np: Our Sovereign Joy; 2010. http://scienceblogs. com/tfk/2010/01/bill_dembski_creationist.php. Accessed 14 Feb 2010.

Dembski WA, Wells J. The design of life: discovering signs of intelligence in biological systems. Richardson: Foundation for Thought and Ethics; 2007.

DeWolf D, Cooper S, West JG. Legal analysis of the Alabama House substitute for SB. Seattle: Center for Science and Culture; 2004. http://www.discovery.org/a/2044. Accessed 17 Feb 2010.

Discovery Institute. Who is this book for? Explore Evolution website; n.d. http://www.exploreevolution.com/who is this for.php. 1090 Accessed 1 Nov 2009.

Discovery Institute. Major grants help establish Center for Renewal of Science and Culture. Discovery Institute Journal. 1996.

Discovery Institute. The wedge strategy. Seattle: Center for the Renewal of Science and Culture; 1998. http://www.antievolu tion.org/features/wedge.html. Accessed 27 Oct 2009.

Discovery Institute. Fighting for academic freedom. Discovery Institute Views. 2006. http://www.discovery.org/scripts/viewDB/ filesDB-download.php?command=download\&id=695. Accessed 30 Oct 2009.

Discovery Institute. Model academic freedom statute on evolution. Seattle: Academic Freedom Petition; 2007. http://www. academicfreedompetition.com/freedom.php. Accessed 30 Oct 2009.

Discovery Institute. David DeWolf on the academic freedom bill. Seattle: Intelligent Design the Future; 2008. http://www.idthefuture.com/ 2008/06/david_dewolf_on_the_louisiana.html. Accessed 30 Oct 2009.

Discovery Institute. 200 years after Darwin: what didn't Darwin know? (video). Seattle: Intelligent Design the Future; 2009a. http://www. idthefuture.com/2009/02/200 years_after_darwin_what_di.html. Accessed 8 Nov 2009. 
Discovery Institute. Science \& faith: friends or foes? Conference at Southwestern Seminary, Fort Worth, TX; 2009b (23-24 Oct). http://www.discovery.org/e/901. Accessed 13 Nov 2009.

Edwards v. Aguillard, 482 U.S. 578. 1987. http://www.law.cornell. edu/supct/html/historics/USSC CR 04820578 ZO.html. Accessed 25 Oct 2009.

Edwords F. Victory in Arkansas: the trial, decision, and aftermath. Creation/Evolution 1982;3(1):33-45. http://ncse.com/webfm_send/ 1137. Accessed 8 Nov 2009.

Epperson v. Arkansas, 393 U.S. 97. 1968. http://www.law.cornell.edu/ supct/html/historics/USSC_CR_0393_0097_ZO.html. Accessed 2 Nov 2009.

Evans S. Evolution: still deep in the heart of textbooks. Oakland: Reports of the National Center for Science Education. 2003;23 (5-6):5-6. http://ncse.com/rncse/23/5-6/evolution-still-deepheart-textbooks. Accessed 15 Feb 2010.

Forrest B. Expert witness report. 2005a. Kitzmiller et al. v. Dover Area School District. http://ncse.com/webfm_send/328. Accessed 14 Nov 2009.

Forrest B. From "creation science" to "intelligent design": Tracing ID's creationist ancestry. 2005b. http://www.creationismstrojanhorse. com/Tracing_ID_Ancestry.pdf. Accessed 25 Oct 2009.

Forrest B. Supplement to expert witness report. 2005c. Kitzmiller et al. v. Dover Area School District. http://ncse.com/webfm_send/326. Accessed 25 Oct 2009.

Forrest B. Testimony in Kitzmiller et al. v. Dover Area School District. 2005d. http://www.talkorigins.org/faqs/dover/day6am2. html\#day6am640. Accessed 13 Nov 2009.

Forrest B. Bobby Jindal's creationist talking points. np: Talk to Action. 2007a. http://www.talk2action.org/story/2007/10/15/222041/63. Accessed 14 Nov 2009.

Forrest B. Understanding the intelligent design creationist movement: its true nature and goals. Washington: Center for Inquiry; 2007b. http://www.centerforinquiry.net/uploads/attachments/intelligentdesign.pdf. Accessed 30 Oct 2009.

Forrest B. The truth about SB 733: WWL TV interviews with Barbara Forrest. np: Louisiana Coalition for Science. 2008a. http:// lasciencecoalition.org/2008/06/15/truth-about-sb-733/. Accessed 17 Feb 2010.

Forrest B. Message to Louisiana school districts: the LA Science Education Act's religion disclaimer won't protect you. np: Louisiana Coalition for Science. 2008b. http://lasciencecoalition.org/2008/10/ 18/message-to-louisiana-school-districts/. Accessed 13 Nov 2009.

Forrest B. Nothing new under the sun: the Louisiana Science Education Act. Free Inquiry. 2009;29(2):34-6. http://www.secularhumanism. org/index.php?section=library\&page $=$ forrest 292 2. Accessed 30 Oct 2009 .

Forrest B, Gross PR. Intelligent design has distinctly evolutionary nature. Quincy: Science \& Theology News; 2004. http://web.archive.org/ web/20041204151447/stnews.org/books_authors_1204.html. Accessed 13 Nov 2009.

Forrest B, Gross PR. The wedge of intelligent design: retrograde science, schooling, and society. In: Koertge N, editor. Scientific values and civic virtues. New York: Oxford University Press; 2005. p. 191-214. http://www.creationismstrojanhorse.com/ Koertge Chap 12.pdf. Accessed 14 Nov 2009.

Forrest B, Gross PR. Biochemistry by design. Trends Biochem Sci. 2007a;32(7):301-10. doi:10.1016/j.tibs.2007.06.001.

Forrest B, Gross PR. Creationism's Trojan horse: the wedge of intelligent design. 2nd ed. New York: Oxford University Press; 2007b.

Foundation for Thought and Ethics. Faqs. Richardson: Design of life website. n.d. http://www.thedesignoflife.net/faqs.asp. Accessed 4 Nov 2009.

Hartwig M. Challenging Darwin's myths. Moody Magazine. 1995. http://www.leaderu.com/orgs/arn/dardoc1.htm. Accessed 25 Oct 2009.
Helms JT. A book review: the theistic evolution of William A. Dembski of Southwestern Baptist Theological Seminary, "The End of Christianity". np: Our Sovereign Joy. 2009. http:// oursovereignjoy.blogspot.com/2009/12/book-review-williamdembskis-end-of.html. Accessed 14 Feb 2010.

Institute for Creation Research. ICR research. n.d. http://www.icr.org/ research/. Accessed 7 Nov 2009.

Internet Movie Database. Expelled: no intelligence allowed. 2008. http://www.imdb.com/title/tt1091617/. Accessed 14 Nov 2009.

Johnson PE. Darwin on trial. Washington: Regnery Publishing; 1991.

Johnson PE. The wedge: breaking the modernist monopoly on science. Touchstone. 1999. http://www.touchstonemag.com/ archives/article.php?id=12-04-018-f. Accessed 23 Oct 2009.

Johnson PE. American Family Radio broadcast. 2003.

Keith B. Scopes II: the great debate. Shreveport: Huntington House, Inc.; 1982.

Kitzmiller et al. v. Dover Area School District. 2005. http://www. pamd.uscourts.gov/kitzmiller/kitzmiller_342.pdf. Accessed 25 Oct 2009.

Louisiana Act 473 (SB 733). Louisiana science education act. 2008. http://www.legis.state.la.us/billdata/byinst.asp? sessionid= 08rs\&billtype $=$ SB\&billno=733. Accessed 30 Oct 2009 .

Louisiana Act 685. Balanced treatment for creation-science and evolution-science act. 1981. http://www.legis.state.la.us/lss/ search.asp? RS=RS\&SearchString=Balanced+Treatment. Accessed 27 Oct 2009

Louisiana Family Forum. Critical thinking in the classroom. 2009. http:// www.lafamilyforum.org/critical-thinking. Accessed 30 Oct 2009.

Louisiana SB 561. Louisiana academic freedom act. 2008 (Regular Session). http://www.legis.state.la.us/billdata/byinst. asp? sessionid $=08$ RS\&billid $=$ SB561\&doctype $=$ ALL. Accessed 30 Oct 2009.

Macias T. Evolution bill up for vote again. Opelousas: Daily World; 2008.

Matsumura M, Mead LS. Ten major court cases about evolution and creationism. Oakland: National Center for Science Education; 2007. http://ncseprojects.org/taking-action/ten-major-court-casesevolution-creationism. Accessed 31 Oct 2009.

Matzke N. Alabama legislature lets SB 336 die without a vote. Oakland: National Center for Science Education; 2004. http://ncse.com/ news/2004/05/alabama-legislature-lets-sb336-die-without-vote00484. Accessed 15 Feb 2010.

Matzke N. But isn't it creationism? The beginnings of "Intelligent Design" in the midst of the Arkansas and Louisiana litigation. In: Pennock RT, Ruse M, editors. But is it science? The philosophical question in the creation/evolution controversy. Amherst: Prometheus Books; 2009. p. 377-413.

McLean v. Arkansas Board of Education. 1982. http://www.talkorigins. org/faqs/mclean-v-arkansas.html. Accessed 25 Oct 2009.

Mead LS. Explore evolution: notes from the field. Rep Natl Center Sci Educ. 2008;28(1):11-2. http://ncse.com/rncse/28/1/exploreevolution-notes-from-field. Accessed 15 Nov 2009.

Meyer SC, Minnich S, Moneymaker J, Nelson PA, Seelke R. Explore evolution: arguments for and against neo-Darwinism. London: Hill House Publishers; 2007.

Moore R. How well do biology teachers understand the legal issues associated with the teaching of evolution? Bioscience. 2004;54 (9):860-5.

Morris HM. Scientific creationism. Public School Edition. San Diego: Creation-Life Publishers; 1974.

National Center for Science Education. Settlement in Hurst v. Newman. 2006. http://ncse.com/news/2006/01/settlement-hurstv-newman-00790. Accessed 15 Feb 2010.

National Center for Science Education. Exploring "Explore Evolution". 2008. http://ncse.com/creationism/analysis/explore-evolution. Accessed 17 Feb 2010 
National Center for Science Education. Chronology of "academic freedom" bills. 2009a. http://ncse.com/creationism/general/ chronology-academic-freedom-bills. Accessed 30 Oct 2009.

National Center for Science Education. Discovery Institute's "Model Academic Freedom Statute on Evolution". 2009b. http://ncse. com/node/4677/. Accessed 30 Oct 2009.

National Center for Science Education. Expelled Exposed (website). 2009c. http://www.expelledexposed.com/. Accessed 14 Nov 2009.

Nelson PA. Life in the big tent: traditional creationism and the intelligent design community. Christian Res J. 2002;24(4):1-7. http://www.equip.org/PDF/DL303.pdf. Accessed 13 Feb 2010.

New York Times. Louisiana to teach 'creation'. Special to the New York Times. 1981.

Numbers RL. The creationists: the evolution of scientific creationism. Berkeley: University of California Press; 1992.

Rachal J. Status assessment: Act 685-Balanced Treatment for CreationScience and Evolution-Science. Baton Rouge: Louisiana Department of Education; 1981. http://www.eric.ed.gov/ERICWebPortal/ contentdelivery/servlet/ERICServlet?accno=ED214781. Accessed 27 Oct 2009

Scott EC. Evolution vs. creationism: an introduction. 2nd ed. Westport: Greenwood Press; 2009.
Scott EC, Branch G. Don't call it "Darwinism". Evol Edu Outreach. 2009;2(1):90-4. http://www.springerlink.com/content/ n47h34357743w4p0/fulltext.pdf. Accessed 11 Feb 2010.

TextAddOns (website). 2003. http://www.textaddons.com/. Accessed 17 Feb 2010.

Thaxton CB, Bradley WL, Olsen RL. The mystery of life's origin: reassessing current theories. Dallas: Lewis and Stanley; 1984. http://themysteryoflifesorigin.org/. Accessed 15 Nov 2009.

Thevenot B. Governor hopefuls say faith personal; but some say beliefs have political effect. New Orleans: The Times-Picayune. 2003 (2 Nov): 1.

Whitcomb JC, Morris HM. The Genesis flood: the biblical record and its scientific implications. Phillipsburg: Presbyterian and Reformed Publishing Company; 1961.

Wiker B. A new scientific revolution. Catholic World Report. 2000. http://us.catholic.net/rcc/Periodicals/Igpress/2000-07/intrview. html. Accessed 15 Feb 2010.

Williams RC. Scientific creationism: an exegesis for a religious doctrine. Am Anthropol. 1983;85(1):92-102.

Witham LA. Where Darwin meets the Bible: creationists and evolutionists in America. New York: Oxford University Press; 2002. 